\title{
A DIVATADAPTÁCIÓ DINAMIKUS MODELLEZÉSE
}

E cikk elsődleges célja egy rendkívül bonyolult és izgalmas jelenség, a divat adaptációs mechanizmusainak ismertetése, valamint a divatadaptáció dinamikus modelljének bemutatása, elemzése és továbbfejlesztése. A tanulmányban szerepel a szerző által kidolgozott ún. általános diffúziós modell is, mely a divatinnovátorok és -követők szegmensének elkülönítése alapján képes kezelni bármely fogyasztói csoporton belüli bármely típusú divat elterjedését.

A divat a gazdasági szféra mind több területén érezteti hatását, és ugyanakkor mind nagyobb mértékben befolyásolja a piaci mechanizmusokat. A divat jelenségének a fogyasztói magatartás szemszögéből történő gazdasági elemzése a divat adaptációs folyamatának vizsgálatán és megértésén alapul. A divatadaptáció az új divat elterjedését jelenti a különböző fogyasztók, illetve fogyasztói csoportok között - elsősorban interperszonális és marketingtevékenység hatására.

A divat elterjedését Adams és McCormick a klubok elmélete (theory of clubs) alapján kísérelte meg leírni. A klubok elmélete abból a tényből indul ki, hogy léteznek olyan javak, amelyek nem tekinthetők sem tiszta közjószágnak, sem tiszta magánjószágnak, hanem valahol e két szélső eset között helyezkednek el. Egy klub létrehozása csak bizonyos számú fogyasztóval lehetséges. A csoportba való belépést egyaránt motiválja a csoporthoz tartozás, a konformitás szükséglete, valamint a másoktól való elkülönülés iránti vágy. Kezdetben, amikor még csak kevés tagja van a klubnak, az újonnan belépők hatására még növekedhet is az eredeti klubtagok hasznossága. Amint azonban túl sok tagja lesz a klubnak, az elveszti exkluzivitását; ennek következtében pedig mind a klub fogyasztói, mind a klubba újonnan belépők által élvezett hasznosság csökkenni fog. (Hámori, 1998) Ezek alapján belátható, hogy a klubjavak köztes jószágként viselkednek: klub megalakításához egy ember nem elegendő, a túl sok tagot számláló klub pedig annak felbomlásához vezet.

Adams és McCormick szerint a divathullám elindulása tekinthető egy klub létrehozásának. Amikor még csak kevesen adaptálják a divatot, nem csökken szignifikánsan a divatinnovátorok fogyasztói hasznossága. Az általuk élvezett hasznosság akár még növekedhet is kezdetben, mivel „az imitáció, az utánzás a hízelgés legőszintébb formája" (Hámori, 1998, pp. 114.). Azonban egy bizonyos ponton túl, amikor már sokan váltak divatkövetővé, csökkenni fog a fogyasztók hasznossága, különösen a divatinnovátoroké, mert már nem képesek magukat elkülöníteni a „tömegtől”. Ekkor az újítók egy új divat(jószág) felé fordulnak. (Hámori, 1998)

A szakirodalom részletesen tárgyalja a divat adaptációs mechanizmusait. A cikkben bemutatott modell szempontjából azonban elsősorban a divathoz csatlakozó fogyasztók két domináns motivációját kell kiemelni, mely a klubok elméletének is fontos meghatározója. Az egyén egyrészt el szeretne különülni a társadalom/a fogyasztók egy csoportjától vagy csoportjaitól, ugyanakkor viszont azonosulni akar a társadalom/a fogyasztók egy csoportjával - ennek következtében ez utóbbiakat utánozza; az előbbiektől pedig igyekszik elfordulni. Ezt a dualitással jellemezhető magatartást elsőként Simmel (2001) írta le és elemezte a múlt század elején. Klaniczay (1982) hasonlóképpen vélekedik; szerinte az új divathoz való alkalmazkodás legerősebb motivációja minden esetben egy meghatározott csoporttal való azonosulás igénye. Másrészről azonban hozzáteszi, hogy a divattól való elfordulásra a legjelentősebb okot az adja, hogy egy olyan csoport csatlakozott a divathoz, amellyel az egyén már nem tud, vagy nem kíván azonosulni. A 
divat jelensége tehát a konformizmus és a társadalmi versengés együttes eredményeként írható le. (Bianchi, 2002) A Matsuyama által kifejlesztett divat evolúciós modell szerint az egyének vagy konformista vagy antikonformista preferenciákkal rendelkeznek. Az utóbbiak a divatújítók (fashion leaders) csoportját alkotják, az előbbiek pedig a divatkövetôkét (fashion followers). (Corneo - Jeanne, 1999) Nakayama és Nakamura (2004) divatmodelljében a társadalmi interakció két változatát veszi figyelembe: a bandwagonhatást és a sznobhatást. Bandwagonhatás esetén pozitív a korreláció az egyén és mások magatartása között. Ez valószínủleg azért következik be, mert a divat vonzerejét közvetlenül befolyásolja a divathoz csatlakozottak száma (minthogy a szociálpszichológia szerint konformitásra törekszik az ember). A sznobhatás a bandwagon hatás ellentéte. A státust kívánó ember a túl népszerű, széles körben elterjedt divatot kerüli.

A divattal foglalkozó közgazdasági szakirodalomban a divatnak többféle matematikai modelljét alkották meg. Az alábbiakban azokat a modelleket említem meg röviden, amelyek a divatot adaptáló egyén fogyasztói hasznosságára vonatkoznak. E modellekben az a közös, hogy a társadalmi interakció valamilyen aspektusból és valamilyen formában beépül a divatot adaptáló fogyasztó hasznossági függvényébe.

Frijters (1998) figyelembe veszi egyrészt a fogyasztó jövedelmének és a megvásárolható divattermék adott időpontbeli árának különbségét. Azt állítja, hogy a státusjószág relatív értéke a jövedelem növekedésével emelkedik; azaz a státust biztosító adott divattermék akkor nyújt nagyobb fogyasztói hasznosságot, ha magasabb a jövedelem. A fogyasztói hasznosság függvény másik összetevője a státusra vonatkozik: a divatjószág adott időpontbeli tulajdonosainak átlagos státusára, valamint arra, hogy mekkora a státus hatása a hasznosságra. A függvény két komponense (a pénzügyi és a státus) között additív összefüggés van.

Corneo és Jeanne (1999) modelljében minden egyén két típus valamelyikébe sorolható: a „kívánatosba” (,desirable type”) vagy a „nem kívánatosba” (,undesirable type”). A fogyasztó hasznossági függvényét befolyásolja az adott csoportba tartozó egyének aránya - minél magasabb - ceteris paribus - az arány, annál nagyobb a hasznosság. Ehhez a tényezőhöz kapcsolódik még egy szigorúan pozitív értékű ízlés paraméter is. A fogyasztó költsége csökkenti a hasznosságot, a jövedelme pedig növeli.

A fentiekben már említett Nakayama - Nakamura modell a társadalmi interakciót a bandwagon- és a sznobhatással fejezi ki, multiplikatív viszony formájá- ban. A bandwagonhatás a hasznossági függvényben az adaptációs rátával szerepel, azaz a divatot adaptálók számának a népességhez viszonyított arányával, a sznobhatás pedig az egységnyi érték és az adaptációs ráta különbségével. A függvénybe beépített két paraméter egyike a sznobhatás bandwagonhatásra való relatív erősségét, a másik pedig a társadalmi interakció erősségét reprezentálja. A hasznosságot csökkentő általános költségkomponens a divatadaptáció gazdasági és pszichológiai költségének, valamint magának a divat attraktivitásának a különbsége. (Nakayama - Nakamura, 2004)

Tanulmányomban Miller - McIntyre - Mantrala (1993) dinamikus divatadaptációs modelljét mutatom be, és egészítem ki - az elméleti keret, a szimbolikus hasznossági függvény, valamint az egyes divat adaptációs elméletek leírásával.

\section{Keret a divatfolyamat megértéséhez}

Miller - McIntyre - Mantrala (1993) alapján elsőként az egyéni döntéshozatali folyamatot vizsgálom, majd ez a döntési folyamat integrálódik a társadalmi szintű elemzés keretébe.

\section{Az egyén szintjén legyen}

- a pozitív (perszonális) szelektív hatás mértéke $\phi$,

- a negatív (perszonális) szelektív hatás mértéke $\alpha$,

- a pozitív szelektív hatás keretében nyújtott információ alapján az egyén által kialakított benyomás arról, hogy melyik stílus hozzáillő egy adott időben és helyen $x_{a}$,

- a negatív szelektív hatás keretében nyújtott információ alapján az egyén által kialakított benyomás arról, hogy melyik stílus nem hozzáillő egy adott időben és helyen $x_{r}$,

- az egyén attraktivitása a becsült/értékelt csoportokhoz $x_{a}$,

- a távolságtartás igénye az ellenszenves csoporttól $c_{r}$, (a $c_{a}$ és $c_{r}$ a általában nem azonos mértékű),

- $c_{c}$ a változással szembeni attitűd.

Ezen kapcsolatok erőssége az egyén interperszonális hatásra való érzékenységét mutatja (1.ábra).

A társadalom minden egyes tagjáról feltételezzük, hogy egyéni döntéshozatali folyamata szerint cselekszik. A döntéshozatali folyamat paraméterei egyénenként különbözőek. Mivel minden egyén befolyásolja a társadalom többi tagját, ugyanakkor pedig minden egyénre hatással van a társadalom többi tagja, a társadalom az egyének közötti függéssel jellemezhető. Az 


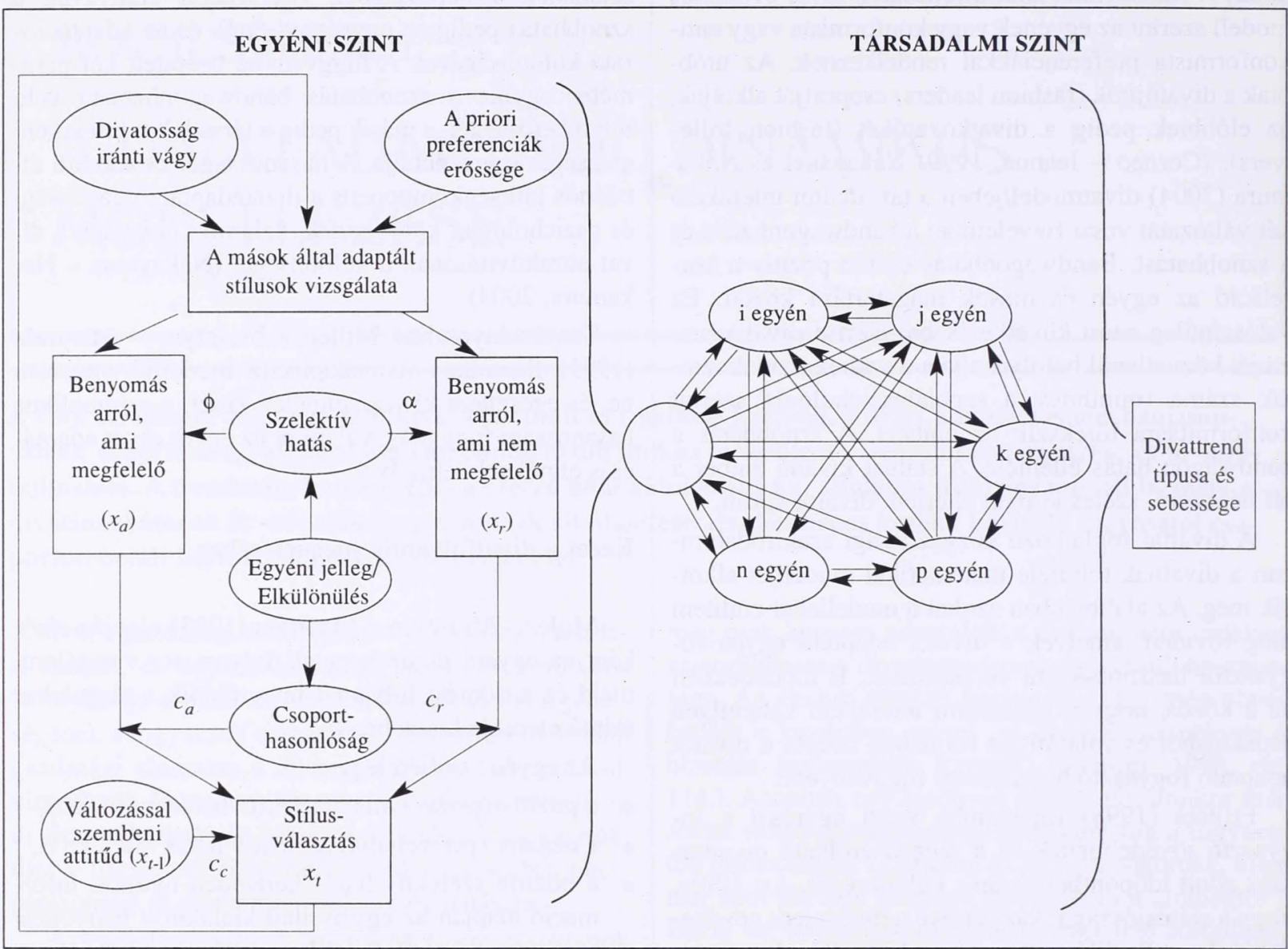

Forrás: Miller, C. M. - McIntyre, S. H. - Mantrala, M. K. (1993): Toward Formalizing Fashion Theory. Journal of Marketing Research, Vol. 30. No. 2. pp. 142-157.

egyén által adaptált stílusinformációt közvetít az egyénről a társadalom többi tagja felé. A társadalom azon tagjai, akiket az egyén befolyásol, valószínűleg felismerik az információk révén a stílusváltást, és így ők is új stílust akarnak adaptálni. Ez a stílusváltoztatás aztán másokra is hatást gyakorol, és a folyamat továbbgyűrűzik. Ily módon dinamikus a divat folyamata, és az adaptáció során egymástól kölcsönösen függnek az egyének. (Miller - McIntyre - Mantrala, 1993) A divatot Bianchi (2002) egymást követő információs folyamatok jelenségeként írja le, és részletesen elemzi e lépcsős folyamatot (cascade modell).

\section{A divatadaptáció dinamikus modellje}

A divat folyamata összetett termékeket kezel és/ vagy ugyanannak a terméknek több tulajdonságát egy- idejűleg; ezért az egyszerúsítés érdekében feltételezzük, hogy az egyének egy tulajdonságnak a szintjét választják egy folyamatos, egy dimenziós térből, amelynek mindkét végén fizikai korlátok vannak. (Miller McIntyre - Mantrala, 1993) Egy tipikus divattermék, a női szoknya esetében például a fogyasztó mindig egy bizonyos hosszúságú darab mellett dönt; a szoknya legfeljebb olyan hosszú lehet, hogy ne akadályozza viselőjét a járásban, és ne koszolódjon a földet érve, valamint maximum olyan rövid lehet, hogy a jó ízlés határát ne lépje túl. Egy másik jó példa a karórák lapjának nagysága: szükséges egy bizonyos méret, hogy az idő jól látható legyen, a túlságosan nagy óra viszont rá sem fér a kézre. Mióta a Swatch divattermékké változtatta a karórákat (Kim - Mauborgne, 2000), azok formája, színvilága, díszítettsége is erősen kitett a divat hatásainak. (Egy meghatározott választására Miller - McIntyre - Mantrala (1993) alapján „stílus-válasz- 
tásként" történik a hivatkozás, mivel egy egyszerú tulajdonságban lévő különbségek gyakran eltérő stílust is jelentenek.)

Az egyén célja minden egyes időperiódusban olyan $x_{I}$-t választani, amellyel maximalizálja hasznosságát. Egy adott $t$ időperiódusban a választott stílus jelentősége a mások által adaptált stílusokhoz viszonyított pozícióján alapul. Mivel az egyén nem tudja pontosan, milyen stílusokat fognak a jelen periódusban választani mások, ezért feltételezhető, hogy az egyén jelenlegi választása az előző, $t-1$ periódusbeli megfigyelt adaptálás alapján történik.

Így az $i$ egyén adaptációja a $t$-edik periódusban

$$
x_{i t}=f\left(\mathbf{X}_{t-1}\right)
$$

ahol $\mathbf{X}_{t-1}=\left(x_{i t-1}, \ldots, x_{n t-1}\right)$ ' az $n$ tagú társadalom $t-1$ periódusbeli adaptációjának oszlopvektora. (Miller McIntyre - Mantrala, 1993)

\section{Preferencia kialakulása}

Az egyént a társadalom többi tagja szelektíven befolyásolja. Az $i$ egyénhez illő stílust a $t$-edik periódusban, azaz $x_{\text {ait }}{ }^{-t}$, a pozitív referenciájú egyének előző periódusban választott stílusainak súlyozott átlaga határozza meg. A társadalom azon tagjai esetében, akikre az egyéni fogyasztó jelentős figyelmet fordít, nagy súlyokat alkalmazunk, a súlyok nem lehetnek negatívak, és összegük egy. Az egyén önmagának 0 súlyt határoz meg, mert a szelektív hatás társadalmilag származtatott. Az $x_{\text {rit }}$ az i egyénhez a $t$-edik periódusban nem hozzáillő stílus, analóg módon származtatható. A szelektív hatás két vektorra történő elkülönítése mutatja az értékelt egyénekhez füződő attrakció szintjét, és az ellenszenves egyénektől való távolságtartás szintjét. Így minden $i=1, \ldots, n$-re

$$
\begin{aligned}
& x_{\text {ait }}=\boldsymbol{\varphi}_{i} \mathbf{X}_{t-1} \\
& x_{r i t}=\alpha_{i} \mathbf{X}_{t-1}
\end{aligned}
$$

ahol $\varphi_{i}$ az $i$ egyén esetén a másokra vonatkozó értékelt súlyok sorvektora, és $\boldsymbol{\alpha}_{i}$ az $i$ egyén esetén a másokra vonatkozó nem méltányolt súlyok sorvektora. (Miller - McIntyre - Mantrala, 1993)

\section{Szimbolikus hasznosság}

Az egyénről feltételezhető, hogy azt a stílust adaptálja, amely maximalizálja hasznosságát. Továbbá feltételezzük, hogy egy stílus hasznossága additívan elkülöníthető függvénye annak, (1) milyen közel van a stílus ahhoz, amit megfelelőnek tart, (2) milyen meszsze van a stílus attól, amit nem tart megfelelőnek, illetve (3) mekkora a távolság a stílus és az egyén által a legutóbb adaptált stílus között.
Feltételezzük, hogy a hasznossági függvény komponensei egyszerü kvadratikus függvényt alkotnak:

$U_{i}\left(x_{i t}\right)=-C_{a i}\left(x_{i t}-x_{a i t}\right)^{2}+C_{r i}\left(x_{i t}-x_{r i t}\right)^{2}-c_{c i}\left(x_{i t}-x_{i t}-x_{i t-1}\right)^{2}$

- ahol $x_{i t}$ az $i$ egyén által a $t$ periódusban választott stílus,

- $U_{i}\left(x_{i t}\right)$ az i egyén hasznossági függvénye,

- $C_{a i}, C_{r i}, C_{c i}$ pozitív paraméterek, melyek az $i$ egyén megfelelését, meg nem felelését, és változását jelölik külön-külön. (Miller - McIntyre - Mantrala, 1993)

A (4) függvény első komponense úgy értelmezhető, hogy minél inkább eltér az $i$ egyén által választott stílus a szerinte hozzáillőtől, annál alacsonyabb a fogyasztó szimbolikus hasznossága. A második komponens szerint minél inkább eltér az i egyén stílusa a nem hozzáillő stílustól, annál nagyobb az élvezett hasznosság. A harmadik komponens pedig azt jelenti, hogy minél nagyobb stílusváltoztatást hajt végre az $i$ egyén a $t$-edik periódusról a $t$-edik periódusra, annál alacsonyabb a hasznossága.

A hasznosság-maximalizálás elsőrendű feltétele:

$$
-c_{a i}\left(x_{i t}-x_{a i t}\right)+c_{r i}\left(x_{i t}-x_{r i t}\right)-c_{c i}\left(x_{i t}-x_{i t-l}\right)=0 .
$$

A hasznosság-maximalizálás másodrendű feltétele:

$$
-c_{a i}+c_{r i}-c_{c i}<0 .
$$

Az (5) egyenletet megoldva az $x_{i t}{ }^{*}$ hasznosság maximalizálására adódik

$$
x_{i t}^{*}=\frac{-c_{a i} x_{a i t}+c_{r i} x_{r i t}-c_{c i} x_{i t-l}}{-c_{a i}+c_{r i}-c_{c i}}
$$

A (2)-t és a (3)-t (7)-be helyettesítve:

$$
x_{i t}^{*}=\frac{-c_{a i}\left(\boldsymbol{\varphi}_{i} \mathbf{X}_{t-1}\right)+c_{r i}\left(\boldsymbol{\alpha}_{i} \mathbf{X}_{t-1}\right)-c_{c i} x_{i t-1}}{-c_{a i}+c_{r i}-c_{c i}}
$$

A (8) egyenlet az $i$ egyén hasznosság-maximalizáló stílusát jelöli a $t$-edik periódusban, $i=1, \ldots, n$.

Az összes egyénre egyidejüleg

$$
\mathbf{X}_{t}=\Omega \mathbf{X}_{t-1}
$$

ahol $\Omega$ a társadalmi hatások rendszereinek négyzetöszszeg mátrixa. Az $\Omega$ diagonál elemei $\left\{a_{i i}\right\}$, melyre

$$
a_{i i}=\frac{-c_{c i}}{-c_{a i}+c_{r i}-c_{c i}} \quad \mathrm{i}=1, \ldots, \mathrm{n},
$$

ez az $i$-edik egyén változással szembeni érdekeltségét mutatja - mindhárom kapcsolathoz viszonyítva. Fi- 
gyelembe véve a hasznosságmaximalizálás másodrendű feltételét (6), és hogy a $c_{c i}$ paraméter pozitív, látható, hogy az $\Omega$ minden diagonál eleme pozitív. Az $\Omega$ fóátlón kívüli elemei:

$$
a_{i j}=\frac{-c_{a i} \phi_{i j}+c_{r i} a_{i j}}{-c_{a i}+c_{r i}-c_{c i}} \quad \mathrm{i} \neq \mathbf{j}
$$

ahol $\phi_{i j}$ és $\alpha_{i j}$ az $i$ egyénnek a $j$ egyénre vonatkozó tisztelet (respect) és ellenszenv (disrespect) súlya. A diagonálon kívüli elemek a $j$-edik fogyasztó $i$-edik fogyasztóra gyakorolt tiszta hatását reprezentálják, ahol a nevező egyszerűen normalizálja ezt a tiszta hatást az $i$-edik fogyasztó három paraméterével. Az $a_{i j}$ zérushoz közeli értéke azt jelenti, hogy az $i$-edik fogyasztó kicsi súlyt ad a $j$-edik fogyasztó adaptált stílusának, amikor maga választ. A pozitív (negatív) érték azt jelenti, hogy az $i$-edik fogyasztó a $j$-edik fogyasztó adaptált stílusához hasonló (stílusától eltérő) stílust kíván adaptálni. Az $a_{i i}$ diagonál elemek és az $a_{i j}$ diagonálon kívüli elemek relatív nagysága értelmezhetô úgy, mint az $i$-edik fogyasztónak az interperszonális hatásra való érzékenysége.

Fontos kiemelni, hogy az $\Omega$ mátrix minden egyes sora 1-gyel egyenlő, mivel bármely adott sornak az elemei az egyes egyénekre gyakorolt relatív hatások összességét jelentik, beleértve az egyénnek előző periódusbeli önmagára gyakorolt hatását. Minden oszlop egy adott egyén hatásának mértékét mutatja a társadalom többi tagjára, és így az oszlopösszegérték egyáltalán nem valószínű, hogy 1 lesz. Egy széleskörűen tisztelt egyénnek magas oszlopösszeg értékkel kellene rendelkeznie, míg egy ellenszenvesnek negatív öszszeggel. Az egyének közötti oszlopsúlyokban lévő különbségek a társadalmi berendezkedésben lévő társadalmi diszkrimináció szintjeként interpretálhatók. (Miller - McIntyre - Mantrala, 1993)

\section{Általános modell megoldása}

A modell megoldása magában foglalja az $x_{i t}=\gamma_{i} \lambda^{t}$ alak megoldását, ahol $\gamma_{i} i=1, \ldots, n$ tetszőleges konstansok, de nem mind zéró és $\lambda$ a bázis nem nulla paraméter (Chiang, 1984). A (9) egyenlet alapján a próbafüggvény bármely $t$-re akkor és csak akkor lesz megoldása a rendszernek, ha

$$
(\Omega-\lambda \mathbf{I}) \gamma=0,
$$

ahol I n-ed rendú egység mátrix és a $\mathbf{0}$ egy tisztán nulla elemekből álló oszlopvektor. Szükséges és elégséges feltétele $\lambda$ értékének meghatározásához - melyre $\gamma$ nem nullvektor - hogy $(\Omega-\lambda \mathbf{I})$ determinánsa nulla legyen. Az $\Omega$ karakterisztikus egyenlete így

$$
\sum_{\mathrm{k}=0}^{\mathrm{n}}(-\lambda)^{\mathrm{n}-\mathrm{k}} \operatorname{tr}_{k}(\Omega)=0
$$

ahol $\operatorname{tr}_{k}(\Omega)$ az $/ \Omega / k$-ad rendű pivot elemeinek összege, és legyen $t r_{0}=1$, valamint $t r_{k}(\Omega)$ az $/ \Omega /$. A (13) karakterisztikus egyenletnek pontosan $n$ gyöke van: $\lambda_{1}$, $\lambda_{2}, \ldots, \lambda_{n}$. A gyökök meghatározása után már kalkulálhatók a $\lambda_{1}, \lambda_{2}, \ldots, \lambda_{n}$ nem null vektorok is. Minthogy minden karakterisztikus gyök hatással van az időre, az általános megoldás az $i$-edik időpontra az $n$ megoldás lineáris kombinációja, azaz

$$
x_{i t}=\sum_{l=1}^{\mathrm{n}} A_{i l} \lambda_{i}
$$

ahol $\lambda_{1}, \lambda_{2}, \ldots, \lambda_{\mathrm{n}}$ az $\Omega$ karakterisztikus egyenletének gyökei és $A_{i l}, A_{i n}$ konstansok, melynek pontos értékei a kiinduló feltételek segítségével meghatározhatók. A karakterisztikus gyökök lehetnek valósak vagy komplexek, pozitívak vagy negatívak, és nagyságukban is eltérhetnek.

Pozitív, valós gyökök esetén: ha a $\lambda_{d}$ domináns gyök, azaz a legnagyobb karakterisztikus gyök nagyobb 1-nél, a társadalmon belül az egyének egyre szélsőségesebb stílusokat adaptálnak az idő előrehaladtával, ahogy a $t$ növekedésével $\lambda_{d}$ exponenciálisan emelkedik. Ez a folyamat addig folytatódik, amíg meg nem közelítik a stílus fizikai vagy célszerűségi határait. Amint az egyén megközelíti a határt, nagyobb hasznosságot jelent számára az ellenkező irányba való elmozdulás, mint a határ felé történő további elmozdulás. Az egyik szélsőséges határtól a másik felé történik elmozdulás. Ez a divattípus a korlátok okozta ciklikus divat. Ha a domináns gyök kisebb, vagy egyenlő 1-gyel, minden egyén egy olyan stílus felé közelít, amely időben állandó. Amikor mindenki ugyanannak a stílusnak az adaptálására törekszik, klasszikus divatról van szó.

Negatív, valós gyökök esete: ha az $\Omega$ mátrix minden karakterisztikus gyöke valós, de néhány közülük negatív, akkor nem folyamatos a divatadaptáció az idő előrehaladtával. Ha a negatív gyökök nagyobbak (kisebbek) mint 1 , akkor az ingadozás növekszik (csökken) az idő múlásával.

Komplex gyökök esete: ha az $\Omega$ mátrix karakterisztikus gyökei között vannak komplexek (Chiang, 1984), akkor a divatadaptáció időbeni lefutása során folyamatos ingadozás van. Ez azért különösen érdekes, mert ez egy szabályos ciklusidőt idéz elő, ahol maga a divatciklus irányt vált, mielőtt a stílus fizikai korlátait elérné. A divatnak ez a típusa a feltétel vagy korlát nélküli ciklikus divat. (Miller - McIntyre Mantrala, 1993) 


\section{A korlátozott $\Omega$ mátrix megoldásai}

Az $\Omega$ mátrixnak a következő alaptulajdonságai vannak:

1. tulajdonság: $A z \Omega$ négyzetes mátrix.

2. tulajdonság: Az $\Omega$ csak valós számokat tartalmaz.

3. tulajdonság: Az $\Omega$ minden sorának elemei egyet adnak összegül, azaz

$$
\sum_{j=1}^{\mathrm{n}} a_{i j}=1
$$

minden $i=, \ldots, n$-re.

4. tulajdonság: $\mathrm{Az} \Omega$ diagonál elemei szigorúan pozitívak, azaz

$$
a_{i i}>0
$$

minden $i=, \ldots, n$-re.

Az elemzés célja (1) megvizsgálni, hogy vajon ezek a modellek tudják e magyarázni az irodalomban leírt divattrendek teljes körét és így tekinthető-e a divat dinamika elfogadható általános alakjának, (2) betekintést nyerni az idő lefutásába, ha a feltételezett társadalmi hatás valóban jelen van a társadalomban, (3) bemutatni, hogy miként használhatók a javasolt modellek a társdalmi hatás megadott rendszeréből származó divat-időszakok vizsgálatához (Miller - McIntyre - Mantrala, 1993).

2. ábra

\section{A divatadaptáció elméleteinek $\Omega$ formái}

$\Omega_{A}=\left[\begin{array}{llllllll}+ & a & a & a & a & a & a & a \\ a & + & a & a & a & a & a & a \\ a & a & + & a & a & a & a & a \\ a & a & a & + & a & a & a & a \\ a & a & a & a & + & a & a & a \\ a & a & a & a & a & + & a & a \\ a & a & a & a & a & a & + & a \\ a & a & a & a & a & a & a & +\end{array}\right]$

$\Omega_{B}=\left[\begin{array}{llllllll}+ & b & b & b & b & b & b & b \\ b & + & b & b & b & b & b & b \\ b & b & + & b & b & b & b & b \\ b & b & b & + & b & b & b & b \\ b & b & b & b & + & b & b & b \\ b & b & b & b & b & + & b & b \\ b & b & b & b & b & b & + & b \\ b & b & b & b & b & b & b & +\end{array}\right]$

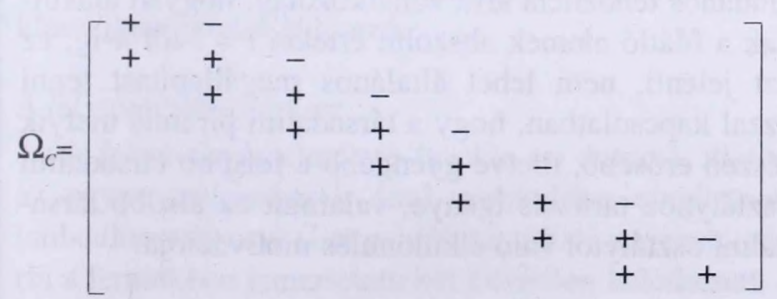

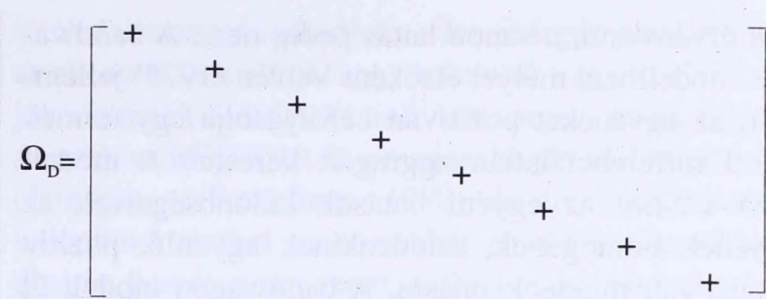
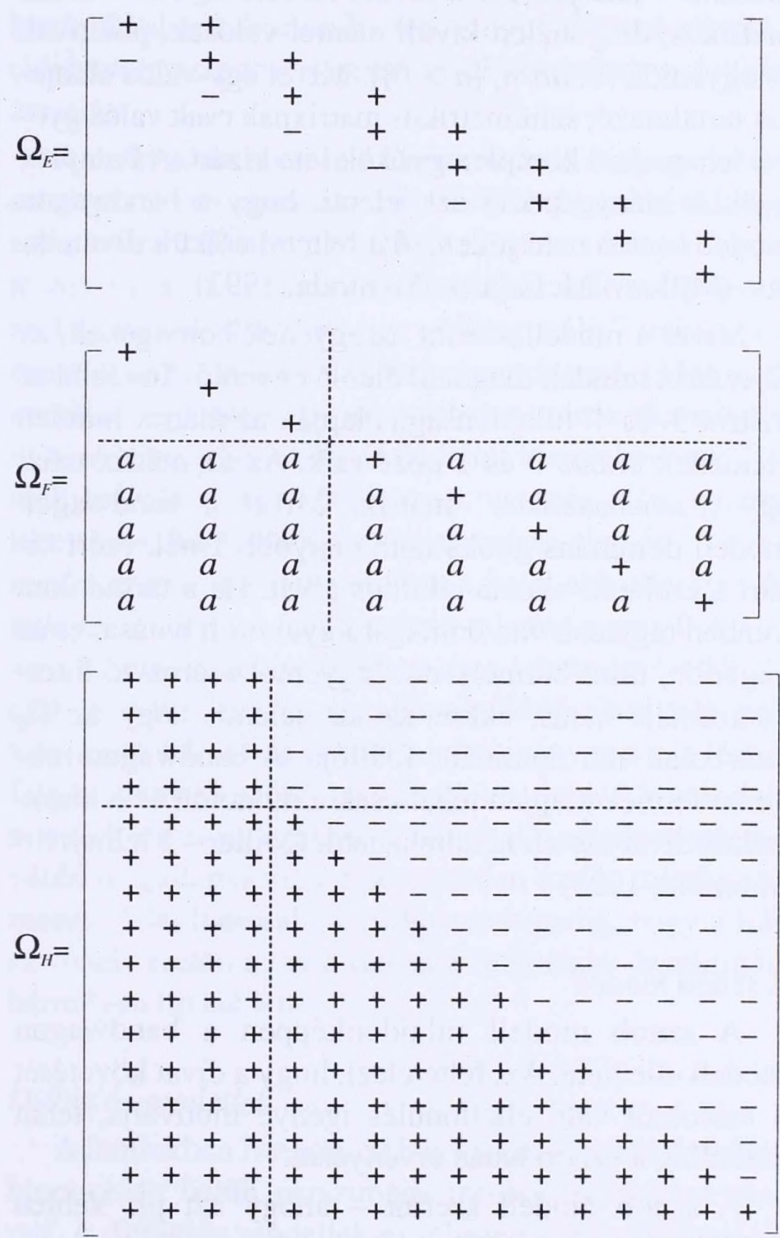

$\Omega_{H}=\left[\begin{array}{ccc}\Omega_{G} & - & - \\ - & + & + \\ - & + & +\end{array}\right]$

Az $\Omega_{A} \Omega_{B} \Omega_{C}$ és $\Omega_{F}$ mátrixok formáinak forrása Miller, C. M. McIntyre, S. H. - Mantrala, M. K. (1993): Toward Formalizing Fashion Theory. Journal of Marketing Research, Vol. 30. No. 2. pp. 142-157., a többi mátrix saját szerkesztésũ.

\section{A bandwagon modell}

A fentiekben már utaltam arra, hogy a divathoz való csatlakozás egyik motivációja a csoporthoz tartozás, a csoporttal való azonosulás. A bandwagon modell azt feltételezi, hogy csupán a konformitás igé- 
nye érvényesül, a sznob hatás pedig nem. A bandwagon modellben, melyet elsőként Veblen (1975) jellemzett, az egyéneket pozitívan befolyásolja egy termék iránti differenciálatlan aggregált kereslet. A modell nem számol az egyéni hatások különbségeivel, az egyének homogének, mindenkinek egyenlo, pozitív hatása van mindenki másra. A bandwagon modell $\Omega$ mátrixa - jelöljük ezt a továbbiakban $\Omega_{A}$-val - szimmetrikus, diagonálon kívüli elemei valósak, pozitívak és egyenlők (2. ábra, $[a>0])$. Mivel egy valós elemeket tartalmazó, szimmetrikus mátrixnak csak valós gyökei lehetnek, a komplex gyökök léte kizárt. A komplex gyökök hiánya pedig azt jelenti, hogy a bandwagon modell esetén nem jellemző a feltétel nélküli divatciklus. (Miller - McIntyre - Mantrala, 1993)

Mivel a modell szerint az egyének homogének, az $\Omega_{A}$ mátrix minden diagonál eleme egyenlő. Továbbá az mátrix 3. és 4 . tulajdonsága alapján az mátrix minden elemének értéke 0 és 1 közé esik. Az $\Omega_{A}$ mátrix tehát egy „sztochasztikus” mátrix. Mivel a bandwagon modell domináns gyöke nem nagyobb 1-nél, ezért kizárt a korlátok okozta ciklikus divat. Ha a társadalom minden tagjának van önmagára gyakorolt hatása, és az nagyobb, mint bármely más egyéntől származó interperszonális hatás, akkor az azt jelenti, hogy az $\Omega_{A}$ mátrixnak van domináns főátlója. A bandwagon modell a fentiek alapján tehát csak a monoton és a klaszszikus divat esetén alkalmazható. (Miller - McIntyre Mantrala, 1993)

\section{A sznob modell}

A sznob modell tulajdonképpen a bandwagon modell ellentéte. Azt feltételezi, hogy a divat követését a másoktól való elkülönülés igénye motiválja, tehát kizárólag a sznob hatás érvényesül.

A sznob modell szerint - ahogy azt pl. Veblen (1975) leírta - egy stílus iránti differenciálatlan aggregált kereslet negatívan befolyásolja az egyéneket. Az előző modellhez hasonlóan az egyének homogének, mindegyiknek egyenlő és negatív hatása van bármelyik másikra. Az $\Omega 3$. alaptulajdonságából következik, hogy ha az $\Omega_{B}$ mátrix (a sznob modell $\Omega$ mátrixa, lásd 2. ábra, $(b<0)$ diagonálon kívüli elemei mind negatívak, akkor az $\Omega_{B}$ mátrix diagonál elemei mind nagyobbak 1-nél. Következésképpen az $\Omega_{B}$ mátrix domináns gyökének nagysága nagyobb 1-nél. A fentiek alapján megállapítható, hogy a sznob modellel jellemezhető társadalmakban nincsenek folyamatos divatciklusok, és klasszikus divattrendek sem. (Miller - McIntyre Mantrala, 1993)

\section{A leszivárgás elmélete}

Három elmélet létezik arra, hogy miként áramlik a divat a különböző fogyasztói csoportok között a társadalmi hierarchiában: a leszivárgás elmélete (trickledown theory), az átszivárgás elmélete (trickle-across theory), és a felszivárgás elmélete (trickle-up theory).

A legrégibb a leszivárgás elmélete, Simmeltől származik a múlt század elejéről. Az elmélet olyan társadalmi hierarchiăt feltételez, amelyben az alsóbb osztályok azonosulni akarnak a felettük állókkal, a felsőbbek viszont különbözni kívánnak az alattuk lévőktől. Az elmélet szerint a divattrendek a társadalmi piramis csúcsán kezdődnek és fokozatosan nyernek elfogadást az egyre alacsonyabb társadalmi szinteken. Az alacsonyabb társadalmi osztályok csak akkor és csak azután fogadják el a divatot, amint a felsőbb osztályok adaptálják azt. A leszivárgás elmélete azt állítja, hogy a felsőbb osztály felsőbbrendű pozíciójának szimbolizálása érdekében adaptál egy új divatot. Amikor azonban az alsóbb osztály a divat adaptálásával kimutatja társadalmi egyenlőségét, a felsőbb osztály elfordul a divattól, és egy újhoz csatlakozik, hogy újból megerősítse felsőbb pozícióját. (Jernigan - Easterling, 1990) Brannon (2001) az adaptáció lépcsőzetességét hangsúlyozza.

A divat leszivárgás elméletének fontos momentuma, hogy minden egyes társadalmi osztály a közvetlenül felette álló társadalmi osztály által adaptált stílus felé törekszik, valamint a közvetlenül alatta lévő társadalmi osztály által adaptált stílustól szeretne különbözni. A leszivárgás elméletének pontos interpretációja szerint az $\Omega$ mátrix (legyen $\Omega_{c}$ ) egy „tridiagonális” mátrix, melynek minden eleme 0 , kivéve a fóátlót (melynek elemei pozitívak), a fóátló feletti átlót (melynek elemei negatívak) és a fóátló alatti átlót (melynek elemei pozitívak). A mátrixban a legfelső társadalmi osztálytól $(i=1)$ a legalsóig $(i=\mathrm{n})$ következnek egymás után társadalmi rétegenként az egyének. (Miller McIntyre - Mantrala, 1993) A diagonál elemek pozitivitása egyértelmű. A főátló alatti elemek azért pozitívak, mert mindenki a közvetlenül felette álló társadalmi csoport által adaptált stílust szeretné követni. Ugyanakkor pedig mivel minden egyén a közvetlenül alatta álló társadalmi osztály által adaptált stílustól eltérni törekszik, a főátló feletti elemek negatívak. Véleményem szerint az egyes diagonálok esetén nincsen általános tendencia arra vonatkozólag, hogyan alakulnak a fóátló elemek abszolút értékei $i=1$-től $n$-ig; ez azt jelenti, nem lehet általános megállapítást tenni azzal kapcsolatban, hogy a társadalmi piramis melyik részén erősebb, illetve gyengébb a felsőbb társadalmi osztályhoz tartozás igénye, valamint az alsóbb társadalmi osztálytól való elkülönülés motivációja. 
A harmadik alaptulajdonság felhasználásával belátható, hogy a diagonál elemek közül legalább egy kisebb 1-nél. További feltételek nélkül azonban nem lehet meghatározni, hogy a domináns gyök nagyobb, vagy kisebb 1-nél. Következésképpen, ha a divatadaptáció a leszivárgás elmélete alapján történik, akkor a divat típusa a fluktuációt leszámítva bármilyen típusú lehet. (Miller - McIntyre - Mantrala, 1993)

\section{Az átszivárgás elmélete}

A tömegpiac és a tömegkommunikáció elterjedésének következtében született meg - a '60-as évek folyamán - az átszivárgás elmélete (trickle-across theory), amelyet tömegpiaci (mass market theory) vagy szimultán adaptációs elméletnek (simultaneous adoption theory) is neveznek. (Brannon, 2001) Az elmélet szerint a divat horizontálisan áramlik a hasonló társadalmi szinteken lévő csoportok között, továbbá minden társadalmi osztálynak vagy csoportnak megvannak a divatinnovátorai. A tömegtermelés és a gyors kommunikáció révén minden társadalmi csoport divatinnovátorai közel azonos időben találkoznak a különböző társzinteken forgalmazott új stílusokkal. Amint az újítók adaptálták a divatot, az egyszerre átáramlik a csoportokon. Az átszivárgás elmélete tehát azt állítja, hogy a divat elterjedése ugyanabban az időben egyszerre több társadalmi osztályban is kezdődhet. Továbbá minden társadalmi osztály vagy csoport tagja a saját csoportjának az innovátorára figyel, és nem pedig egy ismeretlen, magasabb társadalmi osztály- vagy csoportbelire. (Jernigan - Easterling, 1990)

Az átszivárgás elméletének általam kidolgozott $\Omega$ mátrixában (legyen ez $\Omega_{D}$, lásd 2. ábra) a főátlón kívüli elemek mindegyike 0 , mivel az egyének csak a saját társadalmi csoportjukon belül gyakorolnak hatást, és őket is csak ez a szegmens befolyásolja. Az $\Omega$ mátrix 3. alaptulajdonsága alapján így a diagonál elemek mindegyike 1-gyel egyenlő. Ennek alapján a domináns gyök értéke 1 , ez pedig azt jelenti, hogy klasszikus divatról van szó. Nagyon fontosnak tartom azonban hangsúlyozni azt, hogy a klasszikussággal kifejezett „,mozdulatlanság” itt arra utal, hogy az egyes társadalmi szintek között nincs interakció, valamint ehhez kapcsolódóan, hogy minden egyes fărsadalmi szint egyidejüleg ugyanannak a divatnak hódol. Az egyes társadalmi szinteken belül ugyanakkor általában nem a klasszikus divat a jellemző.

\section{A felszivárgás elmélete}

A felszivárgás elmélete (trickle up theory), illetve az egyes szakemberek által szubkultúra elméletnek (subculture theory) (Levy - Weitz, 2004) nevezett teória a fentiekben ismertetetteket követően keletkezett.
A felszivárgás elmélete a leszivárgás elméletének az ellentéte. Azt állítja, hogy a fiatalok vagy az alacsony jövedelműek indítják el a divatot, amely aztán felfelé áramlik az idősebbek és a magasabb jövedelműek felé. (Jernigan - Easterling, 1990) A divat származhat különböző etnikai csoportokból is; a feketék például divatba hozták a rap zenét, és bizonyos hajviseleteket is. (Brannon, 2001) Coates (2003) szerint egyes foglalkozásokkal (pl. börtönőr) összefüggő öltözet adaptációjának eredményeképpen is előfordulhat a felfelé áramlás.

A divat adaptációs mechanizmusának lényege a felszivárgás során ugyanaz, mint a leszivárgás esetén, azzal a fontos különbséggel, hogy ellentétes irányú folyamatok zajlanak le. Ezért az elmélet $\Omega$ mátrixa (legyen ez $\Omega_{E}$, lásd 2. ábra) is egy „tridiagonális” mátrix, és formája az $\Omega_{\mathrm{C}}$ mátrix alapján magyarázható. (Meg kell azonban jegyezni, hogy az egyének a mátrix elemeiként itt most nem feltétlenül a társadalmi hierarchiában elfoglalt helyük szerint következnek egymás után, hanem lehetséges, hogy például az évek száma alapján - csökkenő sorrendben -, amennyiben a fiatal(abb) életkorúak indítják a divatot.) $\mathrm{Az} \Omega_{E}$ mátrix minden eleme 0 , kivéve a fóátlót, valamint az alatta és a felette lévő átlót. A csak pozitív elemeket tartalmazó fóátló alatti átló elemei negatívak, az elkülönülés iránti igény miatt, a fő́tló feletti elemek pedig pozitívak az utánzási szándék miatt. A leszivárgás elméleténél az $\Omega_{c}$ mátrixra tett további megállapítások értelemszerüen az $\Omega_{E}$ mátrixra is igazak. A legfontosabb következtetés pedig, hogy a felszivárgás esetén a divat típusa a fluktuációt leszámítva bármilyen típusú lehet.

\section{Diffúziós modellek}

A fentiekben ismertetett három elmélet a társadalmi hierarchián belüli perszonális mechanizmusokon alapul. A diffúziós modellek ezzel szemben a fogyasztók két szegmensét, az innovátorokét és a követőkét különítik el - a divathoz a divatciklus bevezető, illetve későbbi szakaszaiban történő csatlakozás alapján.

Egy új divat első adaptálóit nevezik divatvezetőknek vagy innovátoroknak (fashion leaders or innovators). Ők azok, akik elsőként hivalkodnak az új divattal társadalmi csoportjukban. (Levy - Weitz, 2004) Két kulcsfontosságú jellemzőjük az innovatív személyiség és az információkereső hajlam. Az egész piacnak csak kis hányadát teszik ki, de segítenek legitimálni és előmozdítani az új divat elterjedését. (Muzinich Pecotich - Putrevu, 2003) Általában fiatalok, képzettek és magas jövedelműek; képesek és hajlandóak a magas árú, státusszimbólumként szolgáló új divatter- 
mékek megvásárlására (Brannon, 2001). Divatkövetők (fashion followers) teszik ki a fogyasztók nagyobbik csoportját. A fogyasztók számos ok miatt válhatnak a divat követőivé annak vezetése helyett: például jobban preferálhatják az utánzást, mint az elsőséget, az új divathoz kapcsolódó bizonytalanság érzése miatt, a divat iránti érdeklődés hiányából fakadóan, de az időés pénzhiány is fontos szerepet játszhat. (Jernigan Easterling, 1990) A divatkövető fogyasztók különböznek abból a szempontból is, hogy a divatciklus melyik szakaszában adaptálják a divatot.

Miller - McIntyre - Mantrala (1993) modelljében az újítók és a követők csoportját homogénnek tételezi fel. A társadalmi hatásokat a felosztott mátrix mutatja (részletesen lásd 2. ábra),

$$
\Omega_{F}=\left[\begin{array}{ll}
D_{1} & 0 \\
D_{2} & D_{3}
\end{array}\right]
$$

ahol a $D_{l}$ négyzetes mátrix az innovátorok minden más egyéntől való függetlenségét reprezentálja. A $D_{2}$ és a $D_{3}$ a csak pozitívan és egyenlő mértékben befolyásolt követők egy feltételezett mintájára vonatkozik. A bandwagon modellhez hasonlóan a követők önmagukra gyakorolt hatása feltételezhetően nagyobb, mint bármely más egyénnek a rájuk gyakorolt hatása, így domináns diagonálja van a $D_{3}$-nak. Mivel az $\Omega$ mátrix 3. alaptulajdonságából következően a $D_{l}$ diagonál elemei 1-gyel egyenlőek, valamint a $D_{3}$ mátrix valójában egy bandwagon modellnek megfelelő mátrix, ez a diffúziós modell a monoton, klasszikus divat leírására képes.

\section{Általános diffúziós modell}

A bemutatott diffúziós modellt nem tartom teljesnek, ezért megkíséreltem annak továbbfejlesztését, és kidolgoztam az ún. általános diffúziós modellt.

Feltételeztem, hogy a divatadaptálóknak (fashion adopters) van két jól elkülöníthető csoportja, az innovátorok és a követők, továbbá hogy e két szegmens egyike sem tekinthető homogénnek. (Ezzel ugyan a modell bonyolultabbá válik, viszont a divat adaptációs mechanizmusa sokkal pontosabban leírható és magyarázható.) $\mathrm{Az}$ általános diffúziós elmélet mátrixának (legyen ez $\Omega_{G}$ ) formája a diffúziós modell $\Omega_{F}$ mátrixából indul ki. Jelen esetben az $\Omega_{G}$ mátrix jobb felső része nem 0 mátrix.

$$
\Omega_{G}=\left[\begin{array}{ll}
D_{1} & D_{3} \\
D_{2} & D_{4}
\end{array}\right]
$$

A $D_{l}$ mátrix az innovátorok önmagukra és egymásra, a $D_{2}$ mátrix az innovátorok követőkre, a $D_{2}$ mátrix a követők innovátorokra, a $D_{4}$ mátrix pedig a követők önmagukra és egymásra gyakorolt hatását mutatja. Az $\Omega_{G}$ mátrixot részletesen lásd 2. ábrán.

A mátrix egyes sorai, illetve oszlopai az egyéneket a divat adaptálásának sorrendjében jelölik. Ez azt jelenti, hogy az első oszlop, illetve az első sor a legelőször divatterméket vásárló fogyasztóra vonatkozik, az utolsó oszlop, illetve az utolsó sor pedig a divatot legutolsóként adaptáló követőre. (A mátrix nem feltétlenül tekinthető arányosnak az innovátorok és a követők száma szempontjából.)

A mátrix bal felső része a divatinnovátorok mátrixa. A főátló feletti elemek pozitívak, de abszolút értékükben csökkennek jobbra haladva. A klubok elmélete szerint ugyanis kezdetben, amikor még csak kevesen csatlakoztak a divathoz, növekszik az első divatozók hasznossága. (Hámori, 1998) Egyre kevésbé növekszik azonban az innovátorok hasznossága, mivel ha mind többen csatlakoznak az új divathoz, egyre nehezebb lesz az innovátorok tömegtől való elkülönülése. A fő́tló alatti elemek is pozitívak, de azok abszolút értékükben növekednek jobbra haladva. Ez azzal magyarázható, hogy az egyén előtt adaptáló $(i=5)$ edik egyén jobban hasonlít hozzá a divat fogyasztói magatartása szempontjából, mint az ( $i=2)$-edik, vagy az ( $i=2$ )-ödik egyén, és az egyént mindig a hozzá leginkább hasonló egyén ösztönzi legnagyobb mértékben a divat adaptálására.

A $D_{3}$ mátrixban csupa negatív érték szerepel. Ezen értékek abszolút értékben növekszenek jobbra haladva. Ez azzal magyarázható, hogy minél később adaptálja valaki az egyénhez képest a divatot, az annál inkább eltérő fogyasztói magatartásjegyekkel rendelkezik az $i$ egyénhez képest. Következésképpen, annál inkább el akar térni az általa adaptált stílustól, azaz abszolút értékben annál nagyobb negatív értéket kalkulál hozzá.

A $D_{2}$ mátrix minden eleme pozitív, mivel a követők az innovátorok hatására kezdik adaptálni a divatot - a követők hasznossága növekszik, ha olyan jellemzőkkel rendelkező termékeket fogyaszthatnak, mint az újítók. Az értékek jobbra haladva abszolút értékben növekszenek. A magyarázat ugyanaz, mint a $D_{1}$ mátrix esetében. Ezen logika alapján felülről lefelé haladva pedig csökkennek az értékek.

$\mathrm{A} D_{4}$ mátrix fő́tló feletti elemei negatívak, mivel a követők hasznosságát csökkenti, hogy utánuk is kapcsolódnak a divathoz - a klubok elmélete alapján ugyanis így túlzsúfolttá válik a klub, és elveszíti érté- 
két a klubtagság. Jobbra haladva az értékek abszolút értékben növekszenek, mivel a késői többség, és még inkább a lemaradók divathoz való alkalmazkodásával a korai többség már nem érzi magát divatosnak, és egy új divat felé szándékozik fordulni. A főátló alatti elemek pozitívak, az értékek az egyes sorokban jobbra haladva növekednek, lefelé haladva pedig csökkennek. Ez ugyanúgy magyarázható, mint a $D_{1}$, illetve a $D_{2}$ mátrix esetében.

Mivel az $\Omega_{G}$ mátrix elemeinek csupán abszolút értékbeli növekedési viszonyaira tettem megállapításokat, a mátrix elemeinek nagyságára pedig nem, ezért nem lehet meghatározni - további feltételek nélkül - a domináns gyök nagyságát. Következésképpen az általános diffúziós modell esetén a korlátok nélküli ciklikus divatot kivéve bármilyen típusú divatról szó lehet.

Az $\Omega_{G}$ mátrixot tekintve további következtetések vonhatók le. Tegyük fel, hogy az $\Omega_{G}$ mátrix oszlopainak diagonálon kívüli elemeit összegezzük, vagyis azokat, amelyek az egyének másokra gyakorolt hatásait mutatják. Ekkor a legnagyobb oszlopösszeg-értékkel rendelkező egyén befolyásolja összességében leginkább pozitívan a többi fogyasztót. Ez egyben azt is jelenti, hogy az általa adaptált stílushoz akarnak legjobban ,,igazodni" a társadalom tagjai. A legkisebb oszlopösszeg-értékkel rendelkező egyén pedig összességében a legnegatívabb hatást gyakorolja többi fogyasztóra. Ez azt jelenti, hogy az általa adaptált stílustól kívánnak leginkább különbözni a fogyasztók. Véleményem szerint egyáltalán nem biztos, hogy a legmagasabb oszlopösszegértékkel az első innovátor, a legalacsonyabbal pedig a legkésőbbi követő rendelkezik. Csak azt lehet feltételezni, hogy a legnagyobb értékkel egy a divathoz viszonylag korán csatlakozó egyén rendelkezik, a legkisebb értékkel pedig egy viszonylag késői követő. Primer kutatás adhat tényleges választ erre a hipotézisre; bár úgy gondolom társadalmi, illetve fogyasztói csoportonként különböző eredmények adódhatnak.

Az általános diffúziós elmélet modellje alkalmazható mind egy $n$ tagú társadalom, mind egy $n$ tagú társadalmi, illetve fogyasztói csoport divatadaptációjának vizsgálatára. A modell $n$ tagú társadalom esetén való használhatósága egyértelmű; a le-, át- és felszivárgás elméletétől eltérően itt a divat adaptálásának (időbeli) sorrendjében követik egymást $i=1$-től $n$-ig az egyének. Másrészt pedig, ha például az átszivárgás elmélete alapján, tehát horizontálisan terjed a divat, akkor ezt a modellt alkalmazhatjuk az egyes társadalmi szinteken történő divatadaptációs folyamatok elemzésére. Ezen túl meghatározott fogyasztói csoportokat is vizsgálhatunk (például a wellness életmódot folytatók élelmiszer-fogyasztási szokásait). A legfontosabb tehát, hogy ez a fajta diffúziós modell bármely „közegben" lezajló folyamatokat képes leírni, az innovátorok és a követők közti hatások alapján.

A marketing szempontjából azért tartom az általános diffúziós modellt rendkívül fontosnak, és a többi modellhez képest jobban alkalmazhatónak, mert alkalmas bármely piacszegmens, illetve fogyasztói csoport divatadaptációs folyamatainak vizsgálatára. Ezt azért nagyon lényeges hangsúlyozni, mert a marketingorientált vállalatok divattermékeikkel, illetve „divatossá” váló termékeikkel rendszerint nem a társadalom egészét, hanem egy vagy néhány piacszegmenst céloznak meg, még akkor is, ha tudatában vannak annak, hogy egy adott divat, különböző formában ugyan, de végiggyürüzik a társadalmon.

$\mathrm{Az}$ általános diffúziós modell mindezek ellenére nem helyettesítheti a le-, át- és felszivárgás elméletet. Amíg ugyanis az utóbbiak esetében a társadalmi hierarchián belüli divatáramláson van a hangsúly, az általános diffúziós modellnél azon, hogy a divatciklus mely szakaszában adaptálja az egyén a divatot, és ez hogyan érinti az interperszonális viszonyokat. Ez azt jelenti, hogy a modellek e két csoportja különböző aspektusból közelíti meg a divatadaptációt. Empirikus kutatásra van szükség annak feltárásához, hogy a szóban forgó modellek milyen mértékben képesek érzékeltetni az egyes divatadaptálók közti különbségeket a divatadaptációs folyamat lefutása során. A divatadaptáció dinamikus modellezése esetén azonban minden esetben az adott gazdasági-társadalmi helyzetnek, illetve a kutatási célnak legmegfelelőbb teóriát kell választani.

\section{A divatadaptáció dinamikus modelljének korlátja és kiegészítései}

A divatadaptáció ismertetett dinamikus modelljének korlátja, hogy nem számol a divatot elutasítókkal. Egy társadalomban, illetve egy fogyasztói csoportban azonban szinte mindig vannak olyanok, akik különböző okokból kifolyólag elutasítják, vagy legalábbis nem adaptálják az új divatot.

$\mathrm{Az}$ általam felírt $\Omega_{G}$ mátrix (esetlegesen) kiegészíthető a divatot elutasítókkal oly módon, hogy plusz sorokkal, illetve oszlopokkal nagyobbítjuk meg (lásd $\Omega_{H}$ mátrix). Ekkor a divatot elutasítók oszlopának azon elemei, amelyek a divatadaptálókra gyakorolt hatást jelölik negatívak lesznek, valamint sorának azon elemei is, amelyek a divatadaptálók rájuk gyakorolt hatását reprezentálják. Ennek egyszerú magyarázata, 
hogy a divatadaptálók és a divatot elutasítók egymástól eltérő stílust kívánnak követni. A divatot elutasítók egymásra gyakorolt hatása viszont pozitív, mivel ezen egyének is tulajdonképpen egy csoportot képeznek. Ha a divatot elutasítók száma relatíve csekély a divatot adaptálók számához képest, akkor valójában ők egy klubot (vagy akár ellendivatot) alkotnak. A divatot elutasítókkal történő kiegészítésnél ugyanazon típusú divatokról lehet szó, mint az általános diffúziós modell esetén.

Miller - McIntyre - Mantrala elméletéből hiányolom azt, hogy nem veszi figyelembe a divatot közvetítő marketinginformációkat. Mivel az általuk felírt függvény egy szimbolikus hasznossági függvény mely alapvetően egy adott stílus választásának a függvénye -, ezért úgy gondolom, hogy elméletileg célszerű lenne beépíteni az adott időszak divatjáról az $i$ egyén által észlelt marketinginformációkat is; ezek ugyanis nagy szerepet játszanak az egyén adott időszakbeli stílusválasztásában, valamint az általa élvezett hasznosságban.

A (4) egyenlet, azaz a szimbolikus hasznossági függvény kiegészítése additív módon, egyszerū kvadratikus formaként, a többi komponenshez hasonlóan lenne célszerü; ahol az $i$ egyén által a $t$ periódusban választott stílus és az $i$ egyén által a stílusról észlelt tetsző, illetve nem tetsző marketinginformációk $t$ periódusbeli súlyozott átlaga szerepel, a szorzót pedig az egyén attraktivitása/távolságtartás igénye jelenti a tetsző/nem tetsző marketinginformációkhoz.

A (4) hasznossági függvény fentiekben leírt kiegészítése azonban rendkívüli módon bonyolítaná és kezelhetetlenné tenné a modellt. Ezért a társadalmon, illetve a fogyasztói csoporton belüli divat adaptációs mechanizmusok vizsgálata esetén véleményem szerint nem célszerú kiegészíteni a modellt.

\section{Összegzés}

Tanulmányom elsődleges célja a divatadaptáció mechanizmusainak ismertetése, valamint a divatadaptáció dinamikus modelljének bemutatása, elemzése és továbbfejlesztése volt. Ennek keretében elsőként Adams és McCormicktól származó klubok elméletével foglalkoztam, majd pedig röviden áttekintettem a divatadaptációt tárgyaló szakirodalmat, valamint a divatot adaptáló fogyasztó hasznosságára vonatkozó matematikai modelleket. A Miller - McIntyre - Mantrala (1993) alapján történő dinamikus modell leírása során részletesen kitértem az egyes divatadaptációs elméletek (bandwagon \& sznob modell, le-, át- és felszivár- gás elmélete, diffúziós elmélet) bemutatására is. Megkíséreltem továbbá egy - az innovátorok és a követők elkülönítésén alapuló - általános diffúziós modell kidolgozását, amelyet marketing szempontból azért tartok rendkívül jól alkalmazhatónak, mert alkalmas bármely piacszegmens, illetve fogyasztói csoport divat adaptációs folyamatainak vizsgálatára, és nem csupán a társadalom egészét képes kezelni. Legvégül a dinamikus modell korlátjaira és lehetséges kiegészítéseire mutattam rá.

Véleményem szerint a divat matematikai modellezésével nemcsak a divat „aktualitása” miatt érdemes foglalkozni, hanem elsődlegesen azért, mert így a verbálisan leírt adaptációs elméletek összefüggései jobban megérthetők, valamint hozzásegíthet új összefüggések felismeréséhez, következtetések levonásához.

\section{Felhasznált irodalom}

Bianchi, M. (2002): Novelty, preferences, and fashion: when goods are unsettling. Journal of Economic Behavior \& Organization, Vol. 47. No. 1. pp. 1-18.

Brannon, E. L. (2001): Fashion forecasting; New York: Fairchild Publications

Chiang, A. C. (1984): Fundamental Methods of Mathematical Economics; Singapore: McGraw-Hill

Coates, J. F. (2003): From my perspective/The future of clothing. Technological Forecasting \& Social Change, 5559 pp. 1-12.

Corneo, G. - Jeanne, O. (1999): Segmented communication and fashionable behavior. Journal of Economic Behavior \& Organization, Vol. 39. No. 4. pp. 371-385.

Frijters, P. (1998): A model of fashions and status. Economic Modelling, Vol. 15. No. 4. pp. 501-517.

Hámori Balázs (1998): Érzelemgazdaságtan/A közgazdasági elemzés kiterjesztése; Budapest: Kossuth Kiadó

Jernigan, M. H. - Easterling, C. R. (1990): Fashion merchandising and marketing; New York: Macmillan

Kim, W. C. - Mauborgne, R. (2000): Új piaci területek létrehozása. Harvard Businessmanager, No. 1. pp. 7-17.

Klaniczay Gábor (1982): Miért aktuális a divat? In: Divatszociológia. I. kötet; Budapest: A Tömegkommunikációs Kutatóközpont Kiadása

Levy, M. - Weitz, B. A. (2004): Retailing Management; New York: McGraw-Hill

Miller, C. M. - McIntyre, S. H. - Mantrala, M. K. (1993): Toward Formalizing Fashion Theory. Journal of Marketing Research, Vol. 30. No. 2. pp. 142-157.

Muzinich, N. - Pecotich, A. - Putrevu, S. (2003): A model of the antecedents and consequents of female fashion innovativeness. Journal of Retailing and Consumer Services Vol. 10. No. 5. pp. 297-310.

Nakayama, S. - Nakamura, Y. (2004): A fashion model with social interaction. Physica A, Vol. 337. No. 3-4. pp. 625-634.

Simmel, G. (2001): Válogatott társadalomelméleti tanulmányok; Budapest: Novissima Kiadó

Veblen, T. (1975): A dologtalan osztály elmélete; Budapest, Közgazdasági és Jogi Könyvkiadó 